\title{
An Assessment of the Contribution of an Analog Forest as a Sustainable Land-use Ecosystem for the Development of Rural Green Economy in Sri Lanka
}

\author{
W.K.D.D. Liyanage ${ }^{1,2,3,{ }^{*}}$, S.N. Gamage ${ }^{3}$, G.D.C. Pushpa Kumara ${ }^{3}$ and L. Xulong ${ }^{2}$ \\ ${ }^{1}$ Forest Department of Sri Lanka, Divisional Forest Office, Nuwara Eliya, Sri Lanka \\ ${ }^{2}$ China University of Geosciences, No. 388, Lumo Road, Wuhan, Hubei, 430074, P.R. China \\ ${ }^{3}$ Land Owners Restore Rainforests in Sri Lanka (LORRIS), Bangamukande Estate, Pitigala, Sri Lanka
}

Date Received: 20-11-2012 Date Accepted: 12-03-2013

\begin{abstract}
Large scale clearing of natural forests for human settlements as well as in the form of tea, rubber and cinnamon plantations resulted forest fragmentation in most natural ecosystems in the wet zone of Sri Lanka which posed massive threats to both nature and the humans including the loss of biodiversity, environmental hazards and increasing poverty. This paper discusses about the potential to develop rural green economy as a result of consolidating these agricultural lands into analog forests as a sustainable land use practice. Bangamukande Estate, a man-made analog forest in Galle District was selected for this assessment. Participatory rural appraisal methods were used to obtain information on resource utilization by the local community in nearby villages. Secondary data of the long term analog forestry establishment programme were also used for analysis the livelihood changes of the people due to the impacts this system. Various interventions had been made to address the issues such as encouraging local farmers to cultivate timber, fruits, spices and medicinal plants, paying them for the environmental services they render and enhancing their income through green employment. The introduction of new sustainable agricultural activities such as bee keeping and planting fruits resulted in the production of value added farm products and organic fruits to be sold in the market. Through environmental based tourism activities such as providing food and accommodation, eco-guidance, and assisting environmental research, the stakeholders are earning a better income supporting the development of a green economy in the country.
\end{abstract}

Key words: Analog forest, Sustainable land-use, Green economy, Green employment

\section{Introduction}

In recent decades, many researchers and sustainable farmers around the world have turned their practices from the extractive industrial model to ecology-based approaches, referred to as eco-agriculture, agro-forestry or analog forest after the value of biodiversity has been taken to consideration (Earles, 2005; Scherr and Shames, 2006). Thousands of farms have contributed to sustainable systems of agro-ecology that promotes biodiversity, recycling of plant nutrients, preventing soil erosion, conserving and protecting water. Also uncultivated portions of agricultural landscapes can provide habitat patches for wildlife, and form corridors that bridging protected areas and allow species to continue their genetic contact with populations that would if not be isolated (Scherr and Shames, 2006). The number of wild plant and animal species in these agro-forests is often as high as in natural forests (Scherr and Shames, 2006; Gamage et al., 2006; Gamage et al., 2007 ; Gamage et al., 2007 ; Liyanage et al., 2009 ; Liyanage, 2009).

*Correspondence: wasantha_cug@yahoo.com

Tel: +94714564411

ISSN 2235-9370 Print / ISSN 2235-9362 Online C2013 University of Sri Jayewardenepura 
Sri Lanka shows the second highest density of the human populations in Asia especially in the wet zone. A growing population, demand for subsistence land and a high proportion of endangered and endemic species within the wet zone of Sri Lanka have resulted in its being declared a critically endangered eco-region; designated as one of the world's 11 biodiversity 'hyper-hot' hotspots (Brookes et $a l ., 2002)$ in requiring extensive conservation investment. However, large portion of the wet zone consists of human managed ecosystems such as agricultural lands, plantation forests and human settlements (Ashton et al., 1995; Pemadasa, 1996; Bambaradeniya et al., 2004). Therefore, the importance of such managed ecosystems cannot be overlooked. The habitat quality and subsequently the richness and abundance of naturally occurring species in such managed ecosystems can be improved further through planned management. This will not only help biodiversity conservation but also improve the productivity of these ecosystems through stabilizing natural processes such as nutrient recycling, pollination, soil conservation and control of pest populations.

Vast extents of Sri Lanka's biodiversity rich lands that were transformed into mono-crop plantations during the colonial era are regenerating in many places due to various natural and anthropogenic causes. Bangamukande Estate, which is situated in Pitigala, Galle, Sri Lanka $\left(06^{\circ} 20^{\prime} 46^{\prime \prime}\right.$ $\mathrm{N}-080^{\circ} 16^{\prime} 26^{\prime \prime} \mathrm{E}-06^{\circ} 20^{\prime} 46^{\prime \prime} \mathrm{N}$ and $080^{\circ} 16^{\prime} 26^{\prime \prime} \mathrm{E}$ ) is an example for a plantation land of 18 hectares consisted of tea, rubber and cinnamon crops that has been deliberately reclaimed as an analog forest as a direct result of the far sighted land use policy of Sri Lanka during 1970 -1977, which introduced crop diversification in uneconomic tea plantations. The land is formed into an undulating terrain that consists of a series of ridges and valleys with an altitudinal range from $100 \mathrm{~m}$ to $300 \mathrm{~m}$. In 1904, ancestors of the present owner planted agricultural mono-crops such as cinnamon, rubber, and tea and continued the cultivation practices until 12 hectares of cinnamon and tea land were transferred to analog forest using a government subsidy, under crop diversification of uneconomic tea lands in 1973. The remaining rubber field of 6 hectares is presently been allowed to regenerate into forestland while been cropped (Wimalasuriya, 2006).

Analog forest is a tree-dominated ecosystem that is analogous in structure and function to the original climax and sub-climax community. With time, the natural succession of any undisturbed forest community is to increase in diversity and stability until a highly complex ecosystem or climax state is reached. When an ecosystem is designed to mimic the indigenous climax state, the efficiency and dynamics of the natural processes can be replicated; such forests are referred to as analog forests. As well to their ecological distinctiveness, analog forests are considered to provide economic benefits (Liyanage et al., 2009 ${ }^{\mathrm{b}}$ ) A wide range of supplies can be produced that may include: fruit, nuts, herbs, cut flowers and cut-foliage, pharmaceuticals, timber and bees honey. The trees and plants in an analog forest will be similar to those in native ecosystems (Liyanage, 2009). They will provide food or microhabitat for native species, but can also supply human needs (Senanayake, 2000; Liyanage et al., 2007). Therefore, this system helps to develop environmentally friendly income generation which is described as green employment in the rural areas of the country (Liyanage, 2009; Liyanage et al., 2009 ${ }^{\mathrm{b}}$ ).

This paper discusses about the potential to develop the rural green economy as a result of consolidating these agricultural lands into analog forests as a sustainable land use practice in a participatory approach model.

\section{Materials and methods}

Two Grama Niladhari (GN) divisions named Bangamukande and Liyanagamakande belongs to Niyagama Divisional Secretariat division in Galle District were included forthis projec (Figure 1, Table 1). The terrain is mostly mountainous and is about $100 \mathrm{~m}-600 \mathrm{~m}$ above MSL situated in the south western low land wet zone of Sri Lanka. The average temperature in the area is $27^{\circ} \mathrm{C}$, with an annual rainfall of between $3500 \mathrm{~mm}-4500 \mathrm{~mm}$. 


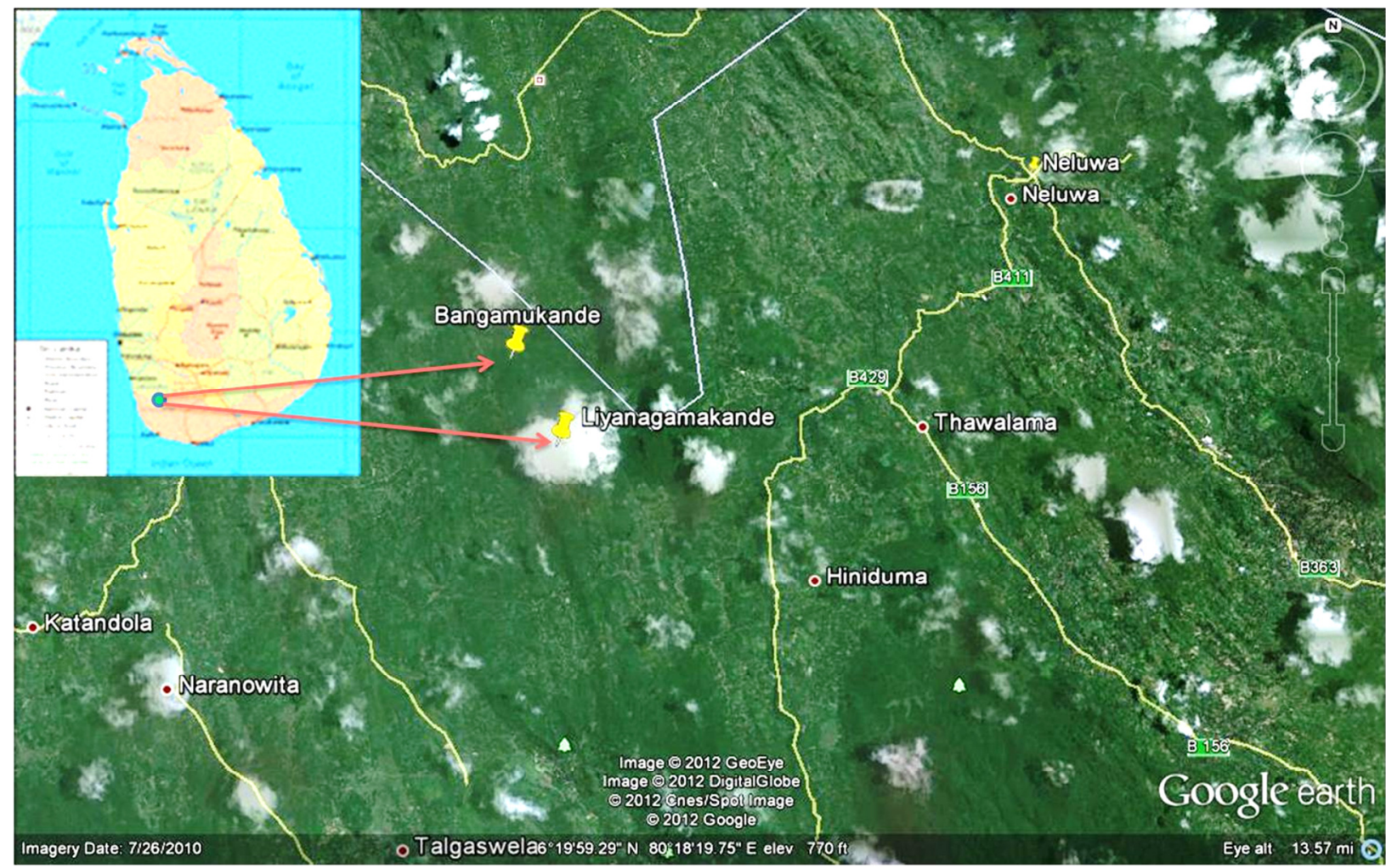

Figure 1: Location of Bangamukande and Liyanagamakande with the surrounding forsted areas

(Source: Google Earth)

Two community based organizations (CBOs) were formed in each GN division which were gathered at the village temple and chief buddhist monk in the temple acted as the patron since the total population in the area are buddhists. Two awareness programs were conducted in the fields of ecofriendly farming activities and the importance of the conservation of biodiversity in the area to increase their knowledge about analog forestry, biodiversity and its importance. Furthermore it included importance about crop diversification and long term impact from mono-crop cultivation.

Table 1: Detailed locality of analog forest establishment including GN divisions

\begin{tabular}{lcrr}
\hline GN Division & GPS location & Height above MSL \\
\hline Liyanagamakande & $080^{0} 16^{\prime} 53.9^{\prime \prime} \mathrm{E}$ & $06^{0} 19^{\prime} 86.2^{\prime \prime} \mathrm{N}$ & $147 \mathrm{~m}$ \\
& $080^{0} 16^{\prime} 41.6^{\prime \prime} \mathrm{E}$ & $06^{0} 20^{\prime} 17.5^{\prime \prime} \mathrm{N}$ & \\
Bangamukande & $080^{\circ} 16^{\prime} 25.9^{\prime \prime} \mathrm{E}$ & $06^{0} 20^{\prime} 45.5^{\prime \prime} \mathrm{N}$ & $120 \mathrm{~m}$ \\
& $080^{\circ} 16^{\prime} 39.9^{\prime \prime} \mathrm{E}$ & $06^{0} 20^{\prime} 15.7^{\prime \prime} \mathrm{N}$ &
\end{tabular}

Lands including home gardens, private plantations, stream reserves, road reserves, temples lands and school gardens were selected for the project. Several tree planting campaigns were organized with the help of the CBOs. Suitable plants were selected according to the topography of the land, type of the crop and the requirements of the land owners. Timber plants, medicinal plants, fruit plants, food plants, shade plants, bamboo plants for the river-banks and some threatened endemic plants were selected for planting (Appendix 1). Timber plants were also distributed among the villagers of surrounding areas to plant in their home gardens which are located out of the forest corridor. Bee keeping boxes were distributed among 30 selected villagers who were very keen to participate in this project component. The programme was started in year 2002 and still continuing. 
The progress of the project was monitored by conducting field visits and interviewing people of the area. One socio-economic survey was done at the begining of the year 2002 when conducting field visits for site selection. Another two surveys were conducted in 2006 and 2008 to gain information on social mobilization of the project.

\section{Results}

A total of 4500 plants belonged to 35 species were planted so far in the forest corridor by this ongoing project, including 10 edible fruit plant species, 16 timber plant species and 10 medicinal plant species (Appendix 1). According to the monitoring results, the plants are growing well since the ecological conditions of the region are favorable to those species. However the survival rate of the plants was approximately $68 \%$ and replanting was also occurred for filling the gaps. Some plants in the selected list for planting activities provide nectar for honey bees. In addition there are many flowering wild plants in the area which bees are using for nectar.

Even though hunting of many wild animal species is prohibited in Sri Lanka, it happens illegally. Before the project begins there were 12 hunters in the area and lot of wild animals such as sambur (Cervus unicolor), purple faced leaf monkey (Semnopithecus vetulus), porcupine (Hystrix indica), pangolin (Manis crassicaudata), wild boar (Sus scrofa) and hare (Lepus nigricollis) etc. were faced to threat of illegal hunting. However as a result of increasing awareness of the people about the importance of biodiversity for sustainable ecosystem, the illegal hunting was reduced about $92 \%$. Also the illegal encroachments of the forested lands were completely stopped as since 2003, there was no any encroachment reported (table 2). Before 2002 the illegal felling of trees from the surrounding forested lands was about 176 trees/ year. When it comes to 2006, the illegal felling rate was reduced by $84 \%$ and by $94 \%$ and $98 \%$ in 2008 and 2011 respectively (Table 2 ).

Table 2: Summary of information obtained from pre and post socio-economic survey (Reduction \% is given in brackets)

\begin{tabular}{lrrrr}
\hline Socio-economic factor & 2002 & 2006 & 2008 & 2011 \\
\hline No. of persons engaged in illegal hunting & 12 & $6(50.00)$ & $1(91.67)$ & $1(91.67)$ \\
Illegal encroachments reported (ha/ year) & 4.25 & $0(100.00)$ & $0(100.00)$ & $0(100.00)$ \\
Illegal Felling (tress/ year) & 16 & $29(8.52)$ & $1094.32)$ & $3(98.30)$ \\
\hline
\end{tabular}

The introduction of new sustainable agricultural activities, such as bee keeping and planting fruits resulted in the production of value added farm products and organic fruits to be sold in the market. Through environmental based tourism activities such as providing accommodation, eco guidance, selling food and fruit for local and international tourists, stakeholders are earning a better extra income. Table 3 shows the development of green employment in the area.

Table 3: No. of people engaged in various green employment activities in the study area

\begin{tabular}{llll}
\hline Green employments & 2002 & 2008 & 2011 \\
\hline Bee keeping & 2 & 45 & 52 \\
Fruit farmers & 1 & 10 & 14 \\
Medicinal herb collectors & 10 & 15 & 13 \\
Toddy tapping & 5 & 12 & 10 \\
Ecological research assistants & 0 & 4 & 6 \\
Eco tourism & 0 & 10 & 15 \\
\hline
\end{tabular}




\section{Discussion}

\subsection{Increasing forest cover in the area}

While much community based re-forestation projects exist, only a few of them are designed to address the need of timber for construction and firewood, by the villagers, while concurrently establishing a corridor to move wild animals. The analog forest restoration in this project is both economic and ecological. It provides an alternative income to the participants while buffers the primary forests from activities such as logging, and the collecting of medicinal plants and fire wood, since the villagers are able to use the multipurpose analog forest area for these purposes. Establishing of timber plants in their home gardens will ensure them to obtain their future timber requirements, without having encroachment to the forested areas and consequently help to conserve the forest indirectly. The project also results in the creation of a passage for the movement of animals from one forest patch to another, which will help to reduce inbreeding depression among animals. In this sense, the program was an effort towards habitat enrichment with the view of serving both human and wildlife needs. Over a long term, this approach would be successful and cost-effective, unlike the attempt at implementing punitive measures, which has failed so far.

\subsection{Social impact of the program}

The participation of the villagers in the programme proved to be highly satisfactorily, and the encouragement given to the people to take part in this project was resulted in their active participation in many components of this project. The target group of the environmental awareness programmes done for each CBOs were school children, village farmers and house wives who are active in Dayaka Sabhas in village temple. Through education and awareness programs, the local community was assisted in accessing science and technology for their everyday life. The school children were more effective to take the conservation message to the public. They showed their active participation in planting activities in community areas and reservations throughout the project. The female community in the villages joined to the temple Dayaka Sabha or Women's society (Mahila Samithiaya), were another effective group for awareness activities as they showed their utmost interest in planting fruit and food plants as well as forest plants in their home gardens. Therefore, students and female community should be considered as a target group in priority when planning any conservation activity or awareness programme.

\subsection{Emerging new paths for green employment}

Development and poverty alleviation are very important for any sustainable project. This project helped to stabilize the economy of the local farmers and minimize the current environmental impact that resulted from mono-crop cultivation. Crop diversification helped stabilize the economy of the local farmers. Some stakeholders have made bee keeping boxes following the model of the distributed bee keeping boxes and increased their production of bee honey, could be considered as a multiplier effect of the programme. The flowering seasons of the trees existing in the area and established by the project are overlapping and continue year round, hence the bee keeping could be managed in a sustainable manner. A set of plants which was considered for this purpose is given in appendix 2 with their flowering seasons. Bee keeping helps to enhance insect pollination, which leads to the protection of plant diversity. In addition, villagers will obtain an extra income from the sale of the bee honey, which is a non-timber forest product.

\section{Conclusion}

Degraded soil conditions, low productivity from cash crops, lack of water retention capacity of the soil are having a direct impact on the local family income. Through analog forest restorations the pattern is to be reversed by increasing the forest cover which will naturally regenerate the area with suitable bio 
diverse habitats allowing animal passage between these lands to the protected areas. Therefore this concept can be used to link the fragmented forest patches in the wet zone of Sri Lanka. The planting activities and the increasing of the tree canopy of the area by this project has satisfied recommendations of the GAP analysis programme of the protected area management project conducted in Sri Lanka in 2006.

In addition, the project addressed a range of fields such as community mobilization, changing of farming activities from mono-crop cultivation to crop diversification, making of strategies for future sustainability of the project by establishing nurseries, educating of the younger generation on environmental issues and the surveying of the biodiversity in the area. It also addressed the taking of measures on poverty alleviation related programs such as promoting organic crops, bee keeping, and introducing other eco friendly income generators which trend to a sustainable development of the society. As well to their ecological distinctiveness, analog forests are considered to provide economic benefits. Non Timber Forest Products are biological products and services, derived mainly from forests ecosystems, and used to make different products for domestic use or marketing. The products such as food, beverages, fodder, fuel, medicine, fibers, bio-chemicals, fur, feathers, bees honey and wax are the value added natural products could be obtained from the analog forest ecosystem. Non timber forest products are more important that timber products as these industries will not harm to the environment, which was agreed with Godoy and Bawa, (1993). Emerging new economic initiatives such as carbon trading and ecotourism has paved the way to ensure higher economic benefits by converting some of the less productive agro ecosystems to semi-natural ecosystems. Therefore, analog forest ecosystem plays a major role in enhancing the development of the rural green economy of Sri Lanka.

\section{Acknowledgements}

Mr. Sunil Wimalasuriya, Mr. Dulan Ranga Widanapathirana, Mr. Sarath Rajapaksha, Mr. Vidupa Rathnayaka and Mr. Piyasena Gunasekara for their tremendous support in field work and the financial assistance provided by Ministry of Environment, Sri Lanka and the China Scholarship Council are acknowledged.

\section{References}

Ashton, S.M., Gunatileke S., de Zoysa N., Dassanayake M.D., Gunatilake N., Wijesundera S., 1995. A field guide to the common trees and shrubs of Sri Lanka. Wildlife Heritage Trust of Sri Lanka. 5 Cotta Road, Colombo, Sri Lanka. 431 pp.

Bambaradeniya, C.N.B., Edirisinghe J.P., de Silva D.N., Gunatilleke C.V.S., Ranawana K.B., Wijekoon S., 2004. Biodiversity associated with an irrigated rice agro-ecosystem in Sri Lanka. Biodiversity and Conservation 13: 1715-1753.

Brookes, T.M., Mittermeier R.A., Mittermeier C.G., Da Fonseca G.A.B., Rylands A.B., Konstant W.R., Flick P., Pilgrim J., Oldfield S., Magin G., Hilton-Taylor C., 2002. Habitat loss and extinction in the hotspots of biodiversity. Conservation Biology 16(4): 909-923.

Earles, R., 2005. Sustainable Agriculture: An Introduction Publication of ATTRA, the National Sustainable Agriculture Information Service. USA.

Gamage S.N., Weerakoon D.K., Gunawardena A., 2006. Can agro-ecosystems function as alternates to natural habitats and link natural habitat patches; A case study of vertebrate diversity in three selected agro-ecosystems in southwestern Sri Lanka. Proceedings of the international conference on Humid Tropical Ecosystems, Kandy, Sri Lanka.

Gamage S.N., Liyanage W.K.D.D., Wimalasuriya S., Gunawardena A., 2007 ${ }^{\mathrm{a}}$. Vertebrates diversity in the 30 years of old analog forest in the Pitigala, Elpitiya. Ruhuna Journal of Science. Faculty of Science, University of Ruhuna, Sri Lanka (1) 162-177. 
Gamage S.N., Weerakoon D.K., Liyanage W.K.D.D., Wimalasuriya S.H., Gunawardena A., $2007^{\mathrm{b}}$. Participatory approach of establishing/consolidating forest corridors: A case study of the (ongoing 'LORRIS') participatory analog forest corridor in the wet zone of Sri Lanka. Eco-summit 2007, Beijing, P.R. China.

Godoy, R., Bawa, K.S., 1993. The Economic Value and Sustainable Harvest of Plants and Animals from the Tropical Rain Forest: Assumptions, Hypothesis and Methods. Economic Botany. 47:215-219.

Liyanage, W.K.D.D., Xulong, L., Gamage, S.N., Weerakoon, D.K., 2007. Vertebrate diversity of a regenerated forest in south-western wet zone of Sri Lanka with special reference to avifauna. Journal of Environmental Research and Development 2(1): 6-19.

Liyanage, W.K.D.D., Gamage, S.N., Xulong, L., Burnet, J.E., 2009a . Analog forest's contribution to biodiversity conservation; a biodiversity assessment of an analog forest on a private property in southwestern wet zone of Sri Lanka. Journal of American Science 5(2): 69-82.

Liyanage, W.K.D.D., Gamage, S.N., Kumara, G.D.C.P., Wimalasuriya, S., Xulong, L., 2009 ${ }^{\text {b }}$ Analog forest eco-system as a sustainable land use for development of rural green economy; an experience from south western wet zone of Sri Lanka. In Proceeding of the ERSEC international conference on sustainable land use and ecosystem conservation, May, 2009, Beijing, P.R. China. UNESCO, Beijing. pp. 79-88.

Liyanage, W.K.D.D, 2009. Assessment of the suitability of an analog forest as a viable biodiversity conservation option in highly fragmented landscapes in the southwestern wet zone of Sri Lanka. PhD. Dissertation. China University of Geosciences (Wuhan), P.R. China. pp.126.

Nekaris, K.A.I., Troni, P., Liyanage, W.K.D.D., 2004. Conserving Sri Lanka's rain forests via conservation education in Bangamukanda, Galle District. Folia Primatologica. 75 (Suppl 1): 399 (Abstract)

Pemadasa, M.A. (1996) The green mantle of Sri Lanka. National Library Services Board, Sri Lanka. 242 pp.

Scherr, S.J. and S. Shames, (2006). Agriculture: a threat or promise for biodiversity conservation. Arborvitoe, The IUCN/WWF Forest Conservation Newsletter.

Senanayake, R. (2000) Analog forestry; an alternative for clear and simplify. ILEIA Newsletter September, 2000. 12-13.

Wimalasuriya, S.H. (2006) Resurrecting Razed Rainforests. Part 1. Wimalasuriya Property Developers, Colombo, Sri Lanka. 35 pp.

Appendix 1: List of plant species and the amount established in the analog forests

\begin{tabular}{llr}
\hline Name of the plant species & Usage & No. of plants established \\
\hline Rambutan (Nephelium lappaceum) & Edible fruit & 200 \\
Wal Jambu (Syzygium aqueum) & Edible fruit & 50 \\
Jambu (Syzygium malaccensis) & Edible fruit & 100 \\
Goraka (Garcinia quaesita) & Fruit/ Spice & 50 \\
Mangosteen (Garcinia mangostana) & Edible fruit & 100 \\
Aligeta-pera (Persea Americana) & Edible fruit & 100 \\
Del (Artocarpus altilis) & Edible fruit & 100 \\
Jak fruit (Artocarpus heterophyllus) & Edible fruit/Timber & 250 \\
Etamba (Mangifera zeylanica) & Edible fruit/Timber & 50 \\
Coconut (Cocos nucifera) & Edible fruit/Timber & 100 \\
Nedun (Pericopsis mooniana) & Timber & 350 \\
Mahogany (Swietenia macrophylla) & Timber & 600 \\
Bu-hora (Dipterocarpus hispidus) & Timber & 50 \\
Hora (Dipterocarpus zeylanicus) & Timber & 50 \\
Eeriya (Enicosanthum acuminatum) & Timber & 50 \\
Walukeena (Calophyllum bracteatum) & Timber
\end{tabular}


Batukeena (Calophyllum thwaitesii)

Hedawaka (Cheatocarpus coriaceus)

Milla (Vitex altissima)

Pihimbiya (Filicium decipiens)

Diya-naa (Mesua thwaitesii)

Naa (Mesua ferrea)

Wenivel (Coscinium penistratum)

Sudu handun (Santalum album)

Kekiriwara (Schumacheria castanaefolia)

Ankenda (Acronychia pedunculata)

Pinibaru (Lijndenia capitella)

Ruk (Horsfieldia iryghedi)

Welipiyanna (Anisophyllea cinnamomoides)

Keta-kela (Bridelia retusa)

Kebella (Aporosa lindleyana)

Walla patta (Gyrinops walla)

Kitul (Caryota urens)

Puwak (Areca catechu)

Bamboo (Bambusa spp.)
Timber $\quad 50$

Timber $\quad 50$

Timber $\quad 100$

Timber $\quad 150$

Timber $\quad 100$

Timber/Medicinal $\quad 50$

Medicinal 100

Medicinal 200

Medicinal 100

Medicinal 150

Medicinal $\quad 50$

Medicinal 200

Medicinal $\quad 50$

Medicinal 100

Medicinal $\quad 50$

Handicraft $\quad 50$

Traeckle/Jaggery/Toddy 100

Medicinal/chewing/Boundary demarcation 200

River bank conservation/ Timber $\quad 400$

Appendix 2: Plants producing nectar for honey bees showing their flowering calendar

\section{Plant species}

\begin{tabular}{|c|c|c|c|c|c|c|c|c|c|c|c|c|}
\hline & $\underset{\Xi}{\stackrel{\Xi}{\Xi}}$ & 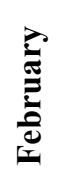 & 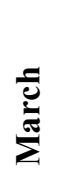 & $\overline{\frac{2}{2}}$ & $\sum^{\vec{\Xi}}$ & $\stackrel{\Xi}{\Xi}$ & $\underset{\Xi}{\Xi}$ & 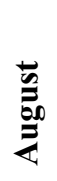 & $\frac{\bar{d}}{\bar{\Xi}}$ & $\begin{array}{l}\dot{0} \\
\frac{0}{0} \\
\stackrel{0}{0}\end{array}$ & 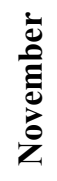 & 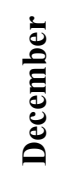 \\
\hline \multicolumn{13}{|l|}{ Cocos nucifera } \\
\hline \multicolumn{13}{|l|}{ Artocarpus heterophyllus } \\
\hline \multicolumn{13}{|l|}{ Coscinium penestratum } \\
\hline \multicolumn{13}{|l|}{ Schumacheria castanaefolia } \\
\hline \multicolumn{13}{|l|}{ Caryota urens } \\
\hline \multicolumn{13}{|l|}{ Areca catechu } \\
\hline \multicolumn{13}{|l|}{ Fahrenheitia zelanicas } \\
\hline \multicolumn{13}{|l|}{ Acronychia pedunculata } \\
\hline \multicolumn{13}{|l|}{ Hevea braziliensis } \\
\hline \multicolumn{13}{|l|}{ Harpullia arborea } \\
\hline \multicolumn{13}{|l|}{ Elaeocarpus serratus } \\
\hline \multicolumn{13}{|l|}{ Vitex altissima } \\
\hline \multicolumn{13}{|l|}{ Prunus walkeri } \\
\hline \multicolumn{13}{|l|}{ Calophyllum trapazifolium } \\
\hline \multicolumn{13}{|l|}{ Mangifera zaylanica } \\
\hline \multicolumn{13}{|l|}{ Mesua thwaitesii } \\
\hline \multicolumn{13}{|l|}{ Mesua ferrea } \\
\hline \multicolumn{13}{|l|}{ Symplocos cochinchinensis } \\
\hline \multicolumn{13}{|l|}{ Bridelia retusa } \\
\hline \multicolumn{13}{|l|}{ Shorea megistophylla } \\
\hline \multicolumn{13}{|l|}{ Dipterocarpus gardneri } \\
\hline \multicolumn{13}{|l|}{ Horsfieldia tryghedi } \\
\hline Stemonoporus canaliculatus & & & & & & & & & & & & \\
\hline
\end{tabular}

